\title{
АТИПОВА ПОВЕДІНКА ВЕДМЕДЯ БУРОГО (URSUS ARCTOS LINNAEUS, 1758) В УМОВАХ ЦЕНТРУ РЕАБІЛІТАЦІЇ ДИКИХ ТВАРИН ГАЛИЦЬКОГО НАЦІОНАЛЬНОГО ПРИРОДНОГО ПАРКУ
}

\author{
Озарків М.В.
}

\begin{abstract}
Атипова поведінка ведмедя бурого (Ursus arctos Linnaeus, 1758) в умовах центру реабілітації диких тварин Галицького національного природного парку. - Озарків М.В. - B даному дослідженні проведено спостереження за поведінкою 4 особин бурого ведмедя в центтрі реабілітаиії диких тварин Галицького НПП. Нами зафіксовано більше 30 поведінкових реакиій, які віднесено до 10 категорій, в тому числі атипова поведінка в формі стереотипї. Результати наших досліджень свідчать про те, щуо поступова адаптація до нових умов проживання та ефективне «збагачення» території утримання є ефективними засобами терапії аномальної поведінки бурих ведмедів. Отримані дані вказують на успішну адаптачію ведмедів до нових умов.
\end{abstract}

Ключові слова: аномальна поведінка, стереотипія, ведмідь бурий, Ursus arctos.

Адреса: Галищький національний природний парк, 77162 с. Крилос., вул. Галицька, 1, Галицький р-н., ІваноФранківська область, е-таil: ozarkivm@ukr.net

\begin{abstract}
Atypical behavior of captive brown bears (Ursus arctos Linnaeus, 1758) in the wildlife rehabilitation center of Galych National Natural Park. - Ozarkiv M.V. - Stereotype behavior is repetitive, unchanging behavior devoid of purposeful function. This type of behavioral deviation can have adverse effects on the physical and mental health of the animals. In the present study, was observed the behavior of 4 individuals of brown bear in the center of rehabilitation of wild animals of Halych National Nature Park. The behavior of the bears was monitored by using of modified ethograms of different authors. We detected more than 30 behavioral reactions, which are classified in 10 categories, including an abnormal behavior in the form of stereotypy. Data analysis was performed by one-way ANOVA test using Statistica 12 software. The results of the research indicate that gradual adaptation to new living conditions and effective enrichment of the environment are an effective way of therapy for abnormal behavior of captive brown bears. The obtained data indicate a successful adaptation of Halych National Nature Park captive brown bears to new conditions. For a more detailed analysis of the behavior of captive bears, it is necessary to use an individual approach, to have detailed information about the past animals, captive conditions, food and medical treatment. The lack of background data on animals often complicates their rehabilitation and adaptation to new conditions of maintenance and analysis of the condition as a whole. In general, a diverse and long-term environment enrichment program is a way to permanently release bears from stereotypical behavior.
\end{abstract}

Key words: abnormal behavior, stereotypy, brown bear, Ursus arctos.

Address: Halych National Nature Park, 77162, Krylos, 1 Halytska street, Ivano-Frankivsk region, Ukraine, e-mail: ozarkivm@ukr.net

\section{Вступ}

Тваринам, які живуть в умовах неволі, як правило притаманна аномальна поведінка, і це може бути одним 3 індикаторів як фізичного стану, так і умов життя тварин в цілому (Mason 2004). Великі хижі тварини, такі як ведмідь бурий (Ursus arctos Linnaeus, 1758) потрапивши в умови неволі, найбільше схильні до розвитку стереотипної поведінки. Основна частина щоденної природної рутини ведмедя бурого пов'язана із реалізацією цілого ряду інстинктів і в основному витрачається на пошук об'єктів живлення (Montaudouin, Le Pape 2004).
Стереотипна поведінка або стереотипія повторювана, незмінна поведінка позбавлена очевидної функції, яка може привести до негативних наслідків для фізичного та психічного здоров'я тварин. Для уникнення аномальної поведінки, покращення здоров'я та умов існування тварин, важливо зрозуміти основні причини стереотипної поведінки, оскільки вони надають фундаментальні дані для подальших наукових досліджень та швидкого діагностування відхилень у поведінці ведмедів. Слід також зазначити, що у дикому середовищі, 
стереотипія не властива для типових моделей поведінки ведмедів (Meyer-Holzapfel 1968).

Існують дві гіпотези походження стереотипної поведінки ведмедів, які перебувають в умовах обмеженого простору. Мотиваційна гіпотеза припускає, що стереотипна поведінка виникає як відповідь на неможливість виконання інстинктивної реакції на зовнішній подразник. Такого роду поведінкові реакції слід розглядати як мотивацію, яка змушує виконувати тварину різноманітні форми активності, тобто як негативну відповідь на подразник (наприклад, голод спонукає тварину до активного фуражування). Даний вид причиннонаслідкових зв'язків між мотивацією та пї реалізацією, підтримує фізичну та психологічну рівновагу тварини, а ii порушення часто вважається однією із основних причин стереотипії (Clubb et al. 2006)

Нейропатологічна гіпотеза вказує на фізіологічну природу стереотипної поведінки, зокрема, на функціональні та структурні зміни центральної нервової системи. У тварин із стереотипією зафіксоване патологічне функціонування таких нейромедіаторів як дофамін та серотонін (Sharman et al. 1982; Vandebroek et al. 1995). Крім того припускають, що аномальні повторювальні рухи виконуються для вивільнення ендорфінів в умовах постійного стресу, спричиненого зовнішніми подразниками.

Для ведмедів зареєстровано багато різних типів аномальної повторювальної поведінки, зокрема стереотипія ротової порожнин: рухи язиком, самооблизування, затискання щелепи; локомоторна стереотипія: топтання на місці, рух по колу, «задній хід», пірнаючі рухи; стереотипія голови: підкидання чи похитування головою. Ведмеді схильні до високочастотної стереотипії в місцях, де вони зазвичай отримують їжу, або в місцях 3 неминучими зовнішніми стресами, такими як зустріч iз агресивними сусідами або спостереження відвідувачів.

Найбільш визнаний спосіб уникнення стереотипії тварин в умовах неволі $є$ так зване «збагачення» інтер'єру вольєру (Podturkin 2015; Podturkin, Salnikova 2018; Maslak, Sergiel 2009). Під «збагаченням» розуміють адаптацію умов живлення та проживання до природної моделі життя диких тварин (Fischbacher, Schmid 1999; Mc Phee 2002; Renner, Plebani Lussier 2002). До ефективних методів урізноманітнення рутини диких тварин відносять групування представників одного виду, навіть якщо вид проявляє солітарний характер у дикій природі.

Після перевезення 4 особин ведмедя бурого в центр реабілітації диких тварин Галицького національного природного парку, в кількох особин спостерігалась стійка аномальна поведінка у формі стереотипії. Була очевидною необхідність провести довгостроковий моніторинг поведінки та оцінити загальну реакцію психологічного та фізичного стану ведмедів на зміни дизайну вольєру та розширення території загалом. Нами проведено роботу зі спостереження за зміною поведінки ведмедів впродовж 1,5 року перебування на території центру реабілітації. Ми припустили, що поступова адаптації до нового місця проживання та зміни умов утримання, позитивно змінять поведінкову активність ведмедів.

\section{Матеріали та методики}

Об'єкти дослідження та умови утримання. Спостереження проводились за 4 особинами бурого ведмедя 3 моменту переселення у центр реабілітації диких тварин Галицького НПП. Спостереження проводили за 3 самицями та 1 самцем ведмедя бурого. Ведмедиця Діна народилась в дикій природі (2001р.), матір вбили браконьєри, а іiі ведмежат віддали до цирку. Пізніше Діну із іншим ведмедем передали до звіринця м. Херсон. 32003 року Діна почала народжувати ведмежат, яких головним чином, iз самого народження продавали до цирків.

В 2003 р. народились Маша, в 2014 р. Мир i Надя. За підтримки зоозахисників та громадських організацій з 2014 року вилучення ведмежат від Діни було припинено. У вересні 2017 року за сприяння ГЕО «Еко-Галич» ведмеді Діна, Маша, Мир і Надя переселені до вольєру Галицького НПП.

Впродовж періоду спостереження всі ведмеді перебували разом у натуралізованому вольєрі із загальною площею $1656 \mathrm{~m}^{2}$ (Рис. 1). В процесі спостереження площа території утримання збільшувалась.

На початковому етапі у вольєрі знаходились такі елементи інтер'єру та збагачення:

- двосекційна маніпуляційна клітка;

- трисекційна барлога та штучний насип 3 двома бетонованими входами, для самостійного облаштування барлоги;

- басейн площею $33 \mathrm{M}^{2} \quad 3$ штучним водоспадом; 
- дерев’яний будинок з платформою;

- 7 годівничок різної складності.

Методи спостереження та аналізу даних. Спостереження за ведмедями Галицького НПП проводили за допомогою модифікованих етограм різних авторів (Forthman, Bakeman 1992; Renner, Plebani Lussier 2002). Етограма безперервної фіксації поведінки являє собою реєстрацію всіх видів діяльності, що здійснює тварина. Цей метод вибірки дуже ефективний для спостереження за соціальною взаємодією між двома або більше тваринами в групі. Прикладами елементів поведінки можуть бути штовхання, колективний біг, боротьба, живлення, різні типи ігрової поведінки та інші. При фіксації поведінкових реакцій 4 ведмедів, особлива увага надавалась атиповій поведінці. Окремими категоріями виведені колективні та солітарні ігри, оскільки ігрова поведінка, вважається хорошим показником позитивного стану тварин (Montaudouin, Le Pape 2004). Слід зазначити, що у ведмедиці Діни впродовж всього періоду перебування в Галицькому НПП спостерігались прояви так званої псевдовагітноті. Цей вид атипової поведінки, як правило має гормональну природу, часто спостерігається в диких умовах, тому не був включений до аналізу (Hissa 1997).

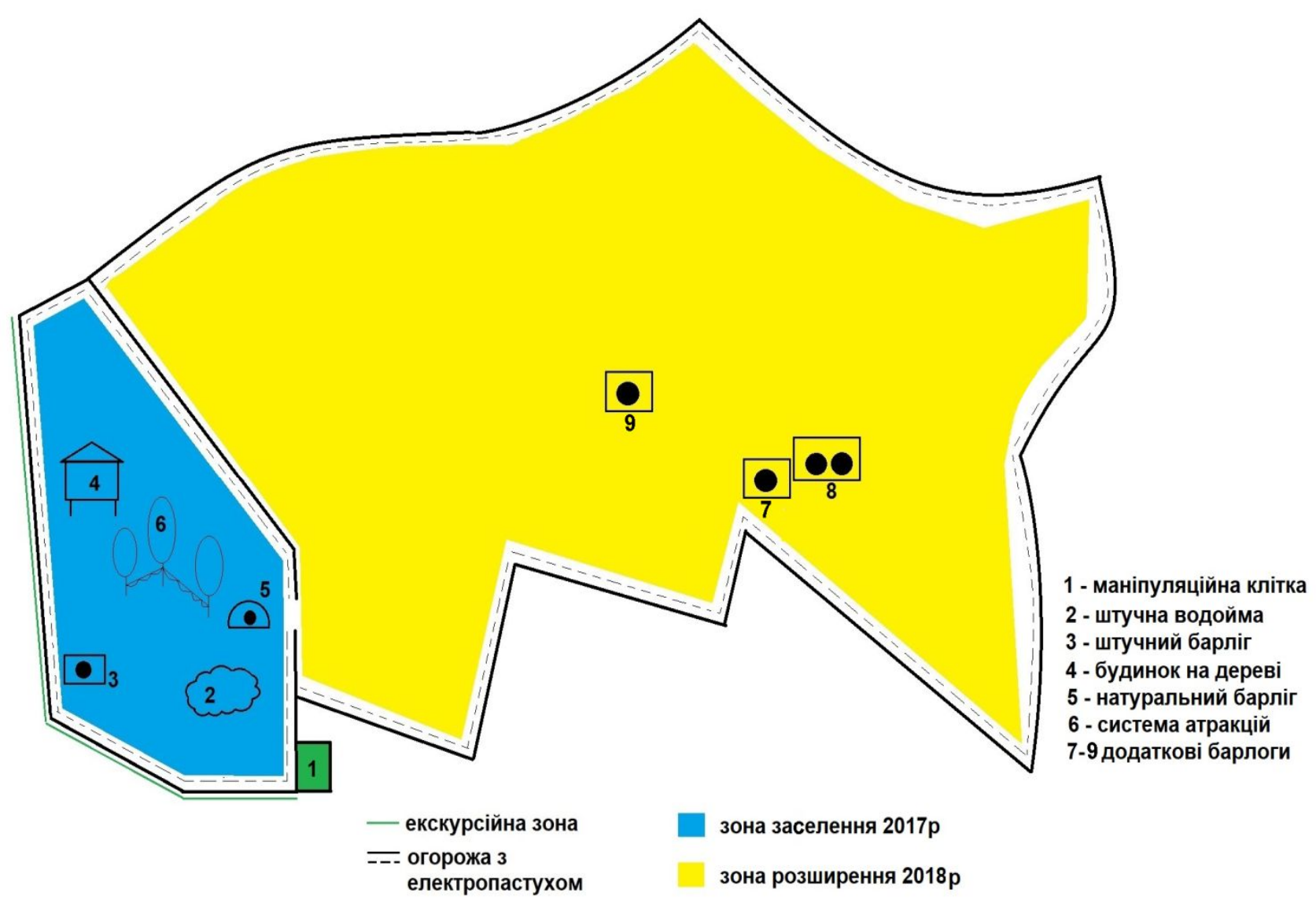

Рис. 1. Схема ведмежого вольєру центру реабілітації диких тварин Галицького НПП

Fig. 1. The scheme of the bear enclosure of the wild animal rehabilitation center of Halych NNP

Спостереження проводили сеансами, 1 раз в день, впродовж 2 годин. Час сеансів змінювався, для спостереженням усього періоду денної активності. Аналіз отриманих даних проводили за допомогою однофакторного дисперсійного аналізу для незалежних груп (ANOVA) iз використанням програмного пакету
Statistica 12. В ході даного аналізу перевіряється нульова гіпотеза про рівність середніх для трьох i більше незалежних груп (якщо $p<0,05$ то нульова гіпотеза відкидається) (Grjibovski 2008). Основними показниками даного аналізу $є$ критерій Фішера $(F)$, та рівень його достовірності $(p)$. Фактором, що виводився на 
аналіз було збагачення дизайну вольєру та поступове розширення площі (досліджені залежні наведені в таблиці 1). Відповідно до цього всі етограми були розділені на три групи та закодовані для аналізу: 1 група - базовий період (спостереження 2017 р до першої зимівлі); 2 група - спостереження до розширення вольєру 2018 p; 3 група - спостереження після розширення вольєру.

Таблиця 1. Класифікатор типів поведінки бурих ведмедів на території вольєру центру реабілітації диких тварин Галицького НПП

Table 1. Classifier of types of brown bears behavior on territory of the enclosure of the wild animal rehabilitation center of Halych NNP

\begin{tabular}{|c|c|c|}
\hline Категорії поведінки & Види поведінки & Примітки \\
\hline \multicolumn{3}{|c|}{ Активна поведінка } \\
\hline $\begin{array}{l}\text { Увага до } \\
\text { маніпуляційної клітки } \\
\text { (МСА) }\end{array}$ & $\begin{array}{l}\text { знаходиться в середині або залишається поблизу клітки, } \\
\text { спостерігає за кліткою з будь-якої частини вольєру }\end{array}$ & \\
\hline $\begin{array}{l}\text { Активність на } \\
\text { території вольєру (VoA) }\end{array}$ & $\begin{array}{l}\text { копає, нюхає дерево або скелю, дряпає землю або дерево, } \\
\text { спостерігає за подіями у вольєрі, нюхає або стежить за } \\
\text { землею під час ходьби }\end{array}$ & $\begin{array}{l}\text { До категорії } \\
\text { відноситься також } \\
\text { спостереження за } \\
\text { відвідувачами }\end{array}$ \\
\hline $\begin{array}{l}\text { Пересування } \\
\text { (Моo) }\end{array}$ & $\begin{array}{l}\text { ходить не нюхаючи землю, біжить або піднімається на } \\
\text { дерево чи елементи збагачення }\end{array}$ & \\
\hline $\begin{array}{l}\text { Соціальна поведінка } \\
(\mathrm{SoB}) *\end{array}$ & $\begin{array}{l}\text { спостерігає, контактує, нюхає або облизує, притуляється до } \\
\text { іншого ведмедя }\end{array}$ & $\begin{array}{l}\text { До цієї категорії } \\
\text { відноситься агресивна } \\
\text { поведінка по } \\
\text { відношенню до інших } \\
\text { ведмедів: } \\
\text { переслідування, } \\
\text { напад, уникання, але } \\
\text { не колективні ігри }\end{array}$ \\
\hline $\begin{array}{l}\text { Колективна гра } \\
\text { (GameC) }\end{array}$ & $\begin{array}{l}\text { бігають на сталій відстані один від одного, імітують } \\
\text { боротьбу, мирне кусання або подряпування лапами }\end{array}$ & \\
\hline $\begin{array}{l}\text { Солітарна гра } \\
\text { (GameS) }\end{array}$ & $\begin{array}{l}\text { піднімає або зачіпає гілки, грається у воді, грається власними } \\
\text { лапами, перекочується або зигзагоподібно бігає }\end{array}$ & \\
\hline \multicolumn{3}{|c|}{ Пасивна поведінка } \\
\hline $\begin{array}{l}\text { Відпочинок } \\
\text { (Rest) }\end{array}$ & $\begin{array}{l}\text { стоїть або сидить, іноді спираючись на стовбур без особливої } \\
\text { уваги до чогось; лежить } 3 \text { відкритими або закритими очима }\end{array}$ & \\
\hline $\begin{array}{l}\text { Особистий догляд } \\
\text { (Geg) }\end{array}$ & $\begin{array}{l}\text { вмивання, чищення язиком, зубами чи лапами, втирання в } \\
\text { шерсть різноманітних субстратів }\end{array}$ & \\
\hline \multicolumn{3}{|c|}{ Аномальна поведінка } \\
\hline $\begin{array}{l}\text { Колова стереотипія } \\
\text { (CyS) }\end{array}$ & безперервний рух по колу & \\
\hline $\begin{array}{l}\text { Маятникова } \\
\text { стереотипія } \\
\text { (WeS) }\end{array}$ & постійні коливальні рухи головою & \\
\hline
\end{tabular}

* До соціальних взаємовідносин нами не віднесено типову чи аномальну статеву поведінку 


\section{Результати та обговорення}

В процесі дослідження зафіксовано проведено 47 сеансів спостереження, загальною протяжністю більше 95 годин. Загалом зафіксовано 2255 поведінкових реакцій різного характеру. Проведений аналіз показав достовірність впливу фактору збагачення та розширення території утримання на загальну модель. Доведено вплив вибраного фактору, із високою достовірністю $(\mathrm{p}<0,05)$ на наступні 6 змінних: увага до маніпуляційної клітки, пересування, соціальні та солітарні ігри, а також два типи атипової стереотипної поведінки (Табл. 2).

Таблиця 2. Результати однофакторного дисперсійного аналізу (ANOVA)

Table 2. Results of one-way ANOVA

\begin{tabular}{cccccc}
\hline & SS & df & MS & F & $p$ \\
\hline MCA & 191,509 & 44 & 4,35248 & $\mathbf{1 2 , 1 1 6 0 7}$ & $\mathbf{0 , 0 0 0 0 6 4}$ \\
VoA & 260,138 & 44 & 5,91223 & 0,73326 & 0,486117 \\
Moo & 200,493 & 44 & 4,55666 & $\mathbf{4 , 5 2 1 8 8}$ & $\mathbf{0 , 0 1 6 3 6 8}$ \\
SoB & 375,638 & 44 & 8,53723 & 2,62307 & 0,083902 \\
GameC & 498,390 & 44 & 11,32704 & $\mathbf{1 2 , 9 8 8 7 6}$ & $\mathbf{0 , 0 0 0 0 3 7}$ \\
GameS & 2885,160 & 44 & 65,57181 & $\mathbf{4 , 3 1 6 7 7}$ & $\mathbf{0 , 0 1 9 4 1 7}$ \\
Rest & 440,460 & 44 & 10,01044 & 0,96963 & 0,387179 \\
Geg & 59,088 & 44 & 1,34291 & 0,07018 & 0,932327 \\
CyS & 1578,036 & 44 & 35,86445 & $\mathbf{3 8 , 4 7 4 1 6}$ & $\mathbf{0 , 0 0 0 0 0 0}$ \\
WeS & 152,988 & 44 & 3,47700 & $\mathbf{1 4 , 1 0 9 6 1}$ & $\mathbf{0 , 0 0 0 0 1 8}$ \\
\hline
\end{tabular}

* Пояснення до скорочень у таблиці 1

Дослідження показує значні відмінності в поведінці ведмедів у періоди заселення, адаптації, збагачення та збільшення площі вольєру (Рис. 2). Вагомі зміни спостерігалися в активній поведінці. Зокрема, після розширення території у ведмедів знизилась активність у маніпуляційній клітці та увага до клітки загалом. Спостерігалось незначне зниження рівня активного пересування по території (без уваги до оточуючих об'єктів). Щодо ігрової поведінки ведмедів, то спостереження показали ріст рівня солітарних ігор (GameS), із середнім показником активності в базовий період $1,37 \pm$ 2,7 (стандартне відхилення) до 8,20 $\pm 2,56$ в період після збагачення та розширення території. Схожу динаміку демонструє рівень колективної ігрової поведінки (базовий період: $1,93 \pm 0,84$, після розширення вольєру $8,5 \pm 1,06$ ).

Атипову поведінку демонстрували 2 iз 4 ведмедів і характерною вона була тільки для старших самиць (Діна, Маша), молоді особини не проявляли жодних аномальних змін поведінки. Загалом проявлялись два типи стереотипії: циклічна або колова стереотипія (Діна) та маятникова стереотипія (Маша). В даному випадку, прояви стереотипії важко пов'язати із статтю особин чи іншими факторами, оскільки ведмеді довгий час перебували в стресових умовах без жодної фіксації змін поведінки та інформації про стан здоров'я загалом. Зрештою відомо, що стереотипічна поведінка дуже поширена у ведмежих, і як правило проявляється у старших особин, які довго перебували в умовах неволі, стресу та піддавались активній експлуатації загалом (Vickery, Mason 2004).

За весь період спостережень нами зафіксовано 65 актів маятникової та 446 циклічної стереотипії. Як видно з графіка (Рис. 3) рівень маятникової стереотипії проявляв постійну тенденцію до зниження. На базовому етапі іiі рівень становив $3,37 \pm 0,46$ і знизився до 0 в період розширення вольєру.

Окремої уваги заслуговує аналіз колової або циклічної стереотипії. Вона проявлялась у ведмедиці Діни, майже весь період перебування у вольєрі Галицького НПП. Спочатку ведмедиця не покидала маніпуляційної клітки, де стереотипія проявлялась 3 дуже високою інтенсивністю $(19,62 \pm 1,49)$. Після адаптації Діна поверталась у маніпуляційну клітку виключно для живлення, там все ще проявлялись напади стереотипії $(6,28 \pm 1,49)$. Після розширення території утримання мало місце падіння рівня стереотипії до 0. 


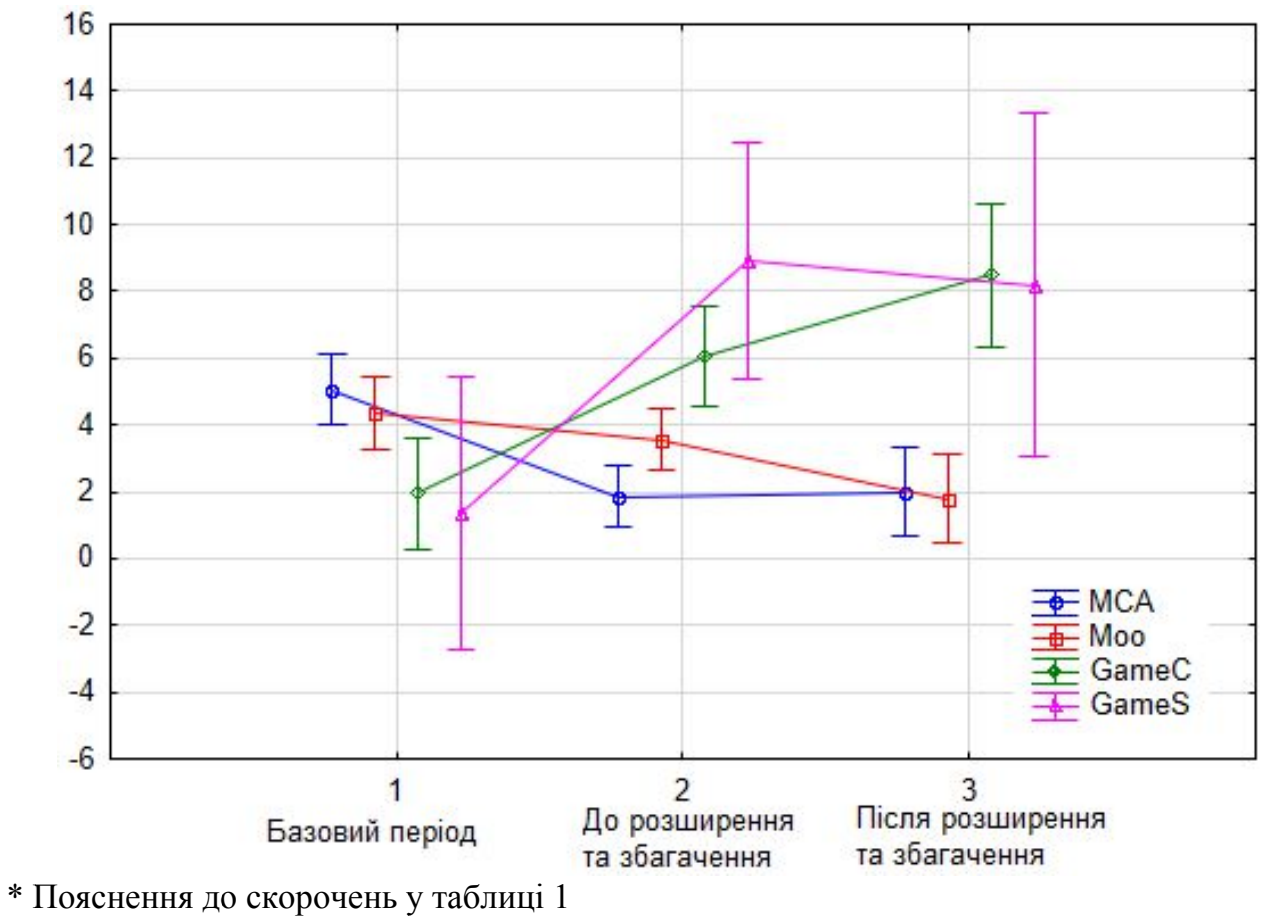

Рис. 2. Графік впливу фактору збагачення на залежні типи активної поведінки бурих ведмедів

Fig. 2. Graph of influence of an enrichment factor on dependent types of brown bear activity

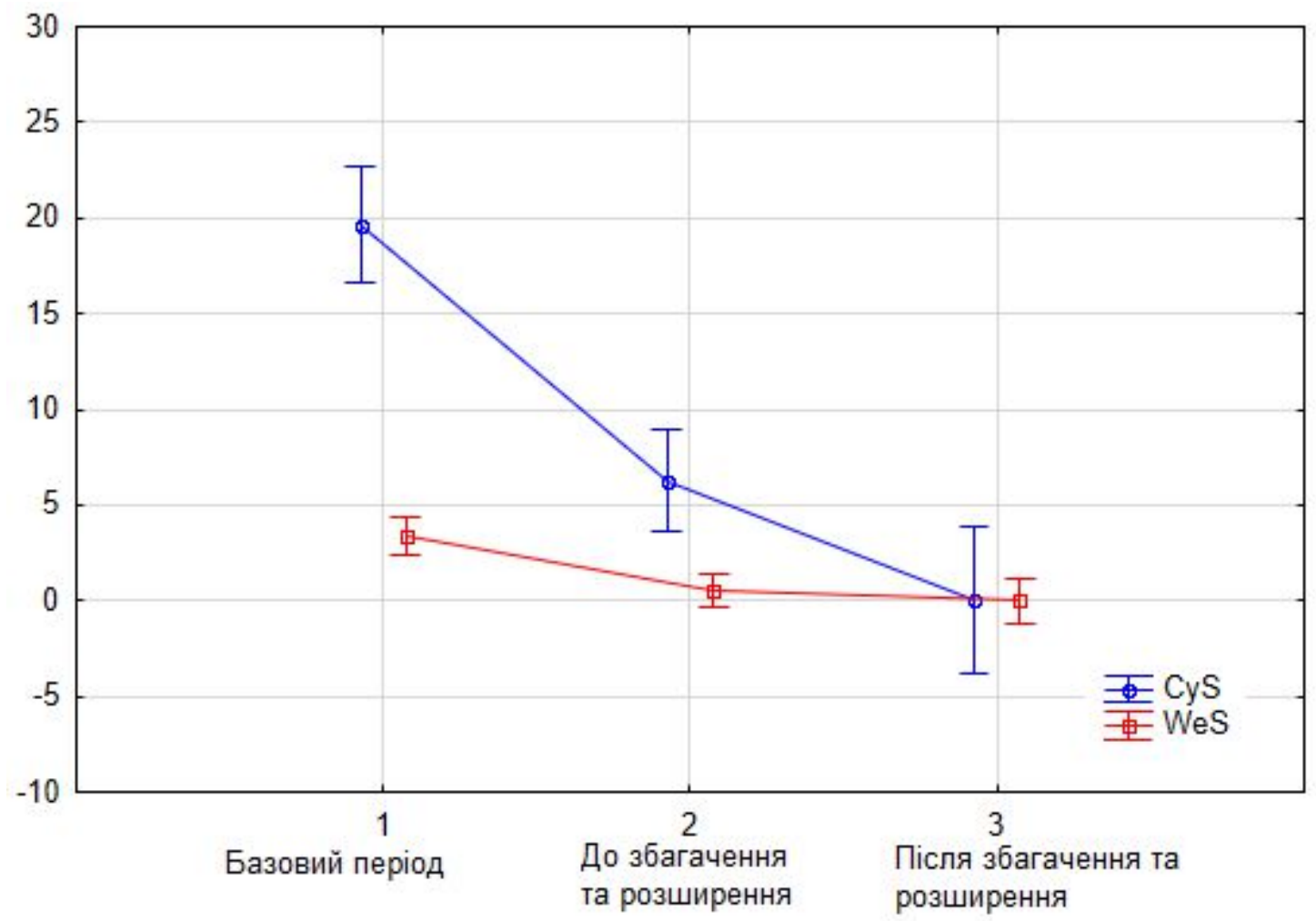

* Пояснення до скорочень у таблиці 1

Рис. 3. Графік впливу фактору збагачення на залежні типи атипової поведінки бурих ведмедів

Fig. 3. Graph of influence of enrichment factor on dependent types of atypical behavior of brown bears 


\section{Висновки}

Результати наших досліджень підтверджують, що поступова адаптація до нових умов проживання та ефективне «збагачення» території утримання $є$ ефективними засобами терапії аномальної поведінки бурих ведмедів. Для більш детального аналізу поведінки ведмедів в умовах неволі, потрібно застосовувати індивідуальний підхід, володіти детальною інформацією про минуле тварини, умови утримання, харчування, медикаментозне лікування, тип експлуатації тощо. Відсутність даних про минуле тварин часто ускладнює їх реабілітацію та адаптацію до нових умов утримання та проведення статистичного аналізу загалом. Очевидно утримання бурих ведмедів в умовах вольєру вимагає постійної зміни внутрішнього дизайну вольєру та ускладнення процесу добування їжі. В цілому, різноманітна і довгострокова програма збагачення середовища - це шлях до сталого звільнення ведмедів від стереотипної поведінки.
CLUBB, R., VICKERY, S., LATHAM, N. (2006) Motivation and motivational explanations for Stereotypies. In: Mason, G, Rushen, J (Eds.) Stereotypic Animal Behaviour: Fundamentals and Applications to Welfare. CABI, Cromwell Press, Trowbridge, p. 12.

FISCHBACHER, M., SCHMID, H. (1999) Feeding enrichment and stereotypic behavior in spectacled bears. Journal of Zoo Biology, 18: 363-371.

FORTHMAN, D.L., BAKEMAN, R. (1992) Environmental and social influences on enclosure use and activity patterns of captive sloth bears (Ursus ursinus). Journal of Zoo Biology, 11: 405-415.

GRJIBOVSKI, A.M. (2008) Analysis of three and more independent groups of quantitative data. Ekologiya cheloveka [Human Ecology], 3: 50-58.

HISSA, R. (1997) Physiology of the European brown bear (Ursus arctos arctos). Annales Zoologici Fennici, 34(4): 267-287.

MARTIN, P., BATESON, P. (1993) Measuring behaviour: An introductory guide. Cambridge University Press, Cambridge.

MASLAK, R., SERGIEL, A. (2009) Captive bears welfare research in Poland, 2007-2009. Wroclaw, Royal Society for Prevention of Cruelty to Animals and Ogolnopolskie Towarzystwo Ochrony Zwierzat (OTOZ) Animals.

MASON, G.J., LATHAM, N.R. (2004) Can't stop, won't stop: Is stereotypy a reliable animal welfare indicator? Animal Walfare, 13: 57-69.

MC PHEE, M.E. (2002) Intact carcasses as enrichment for large felids: effects on on-and off-exhibit behaviors. Journal of Zoo Biology, 21: 37-47.

MC PHEE, M.E, FOSTER, J.S, SEVENICH, M, SAUNDERS, C.D. (1998) Public perceptions of behavioral enrichment: assumptions gone awry. Journal of Zoo Biology, 17(6): 525-534.

MEYER-HOLZAPFEL, M. (1968) Abnormal behavior in zoo animals. In: Fox, M.W. (Ed.). Abnormal behavior in animals). Saunders Company, Toronto, pp. 477-503.

MONTAUDOUIN, S, LE PAPE, G. (2004) Comparison of the behaviour of European brown bears (Ursus arctos arctos) in six different parks, with particular attention to stereotype, Behavioural Processes, 67: $235-244$.
MONTAUDOUIN, S., LE PAPE, G. (2005) Comparison between 28 zoological parks: stereotypic and social behaviours of captive brown bears (Ursus arctos). Applied Animal Behaviour Science, 92(1-2): 129-141.

MORIMURA, N. (2003) A note on enrichment for spontaneous tool use by chimpanzees (Pan troglodytes). Applied Animal Behaviour Science, 82(3): 241-247.

PODTURKIN, A.A. (2015) Obzor praktiki obogascheniya sredy: metody podbora sposobov obogascheniya sredy i otsenka ih rezultativnosti $\mathrm{v}$ usloviyah zooparkov. Nauchnyie issledovaniya $v$ zoologicheskih parkah, 3: 168-200 (in Russian).

PODTURKIN, A.A., SALNIKOVA, T.Yu. (2018) Otsenka effektivnosti obogascheniya sredy samki burogo medvedya (Ursus arctos beringianus) $\mathrm{v}$ Moskovskom zooparke. Nauchnyie issledovaniya $v$ zoologicheskih parkah. 33: 31-43 (in Russian).

PODTURKIN, A.A., VOSCHANOVA, I.P., NEPRINTSEVA, E.S. (2015) Vyiprashivat nelzya, rashazhivat - sposobyi adaptatsii medvedey $\mathrm{k}$ usloviyam nevoli. Yubileynaya konferentsiya «Ot istokov $k$ sovremennosti» 130 let organizatsii psihologicheskogo obschestva pri Moskovskom universitete, Vol. 5. Moscow, Russia, 29.09-01.10, 2015, pp. 430-432 (in Russian).

RENNER, M.J., PLEBANI LUSSIER, J. (2002) Environmental enrichment for the captive spectacled bear (Tremarctos ornatus). Pharmacology Biochemistry and Behavior, 73: 279-283.

SHARMAN, D.F., MANN, S.P., FRY, J.P., BANNS, H., STEPHENS, D.B. (1982) Cerebral dopamine metabolism and stereotyped behavior in early-weaned piglets. Neuroscience, 7: 1937-1944.

VANDEBROEK, I., UGENT, F.O., UGENT, J.C. (1995) Microdialysis study of the caudate nucleus of stereotyping and nonstereotyping bank voles. Proceedings of $29^{\text {th }}$ International Congress of the International Society for Applied Ethology, Exeter, United Kingdom, 3-5, August, 1995, pp. 245-246.

VICKERY, S., MASON, G. (2004) Stereotypic behavior in Asiatic black and Malayan sun bears. Journal of Zoo Biology, 23: 409-430. 